\title{
THE IMPORTANCE OF STRENGTH IN SPORT DANCE PERFORMANCE TECHNIQUE
}

\author{
Adriana Lukić ${ }^{1}$, Snežana Bijelić1 ${ }^{1}$, Meta Zagorc ${ }^{2}$, and Lejla Zuhrić-Šebić ${ }^{3}$ \\ ${ }^{1}$ Faculty of Physical Education and Sport, Banja Luka, Bosnia and Herzegovina \\ ${ }^{2}$ Faculty of Sport, Ljubljana, Slovenia \\ ${ }^{3}$ Faculty of Sport and Physical Education, Sarajevo, Bosnia and Herzegovina
}

SHORT SCIENTIFIC PAPER

DOI: $10.5550 /$ sgia.110701.en.061L

COBISS.BH-ID: 2102808

UDC: 793.3:796

\section{SUMMARY}

Strength is a motor ability that largely determines the features of a move. In the area of conventional sports, that is the very facet that serves as the basis for its importance, which is corroborated by several studies. In sport dance, it is usually demonstrated in the form of repetitive and explosive strength and in the function of introducing nuances in the dynamics of dance performance. How big the importance of some manifestations of strength for the quality of Latin-American and Ballroom dances performance as sport dance disciplines is, is the topic that this paper deals with. The research included 49 sport dancers of both genders, age 12-15. The results of the research point out to the fact that there are different approaches in validation of the contribution of strength for the quality and performance of Latin-American and Ballroom dance. Namely, strength as a motoric ability has statistically significant effects on the quality of Latin-American performance technique, while in Ballroom dances it does not appear to be statistically significant. The obtained differences in the significance of the contribution in the observed dance disciplines are, for sure, a confirmation of the necessity to have an individual approach in planning and programming of training process, particularly for Ballroom and Latin-American dances.

Key Words: strength, influence, sport dance.

\section{INTORODUCTION}

Sport dance can be described as a specific blend of art and sport, which enables the dance pair, in an original way, to express true emotions provoked by different types of music and mold it into a harmonic mixture of beautiful moves. The skill to link and harmonize complex dance structures of different dances, in space and time determined by rhythm, creates a certain esthetical impression which makes the dancer an artist, as well as the need to show and prove even better. The quality of a dancer's technique and the artistic performance depends on a wide spectrum of motor abilities. To date researches in sport dances have yielded some interesting information on the valorisation of individual motoric abilities in the area of technical performance of certain dance disciplines (Kostić, 1997; Lukić, 2006; Lukić, Bijelić, \& Jovanović, 2008; Lukić, 2010; Uzunović, 2008). Likewise, numerous researches from the dance area also corroborate a great influence of basic motoric abilities on a successful dance expression (Lukić, 2006; Uzunović, 2004; Uzunović, Kostić, Zagorc, Oreb, \& Vlašić, Oreb, \& Leščić, 2009). Given the kinetic structure of dance technique, that is, the dance activity in general, it can be said that the most active is the caudal part of the body, which is also the "basic"motor of the move. The lower limbs, their muscles and the abdominal part of the body are mostly responsible for a successful implementation of the tasked dance technique. The ability to contract them swiftly and to relax them determines the necessary dynamics of the dance performance, the ability to react timely with specific muscle groups influences rational utilization of the dancer's energy, as well as the very appearance of muscles largely contribute to the esthetic expression of the move performance. The strength motoric ability in dance activities plays an important role. It appears in different manifestations, and the type of dance activity determines the level of utilization 
of its potentials. In sport dance, specifically, it is mainly present in the form of repetitive and explosive muscle potential, and there are numerous researches that proved it (Kostić, 1997; Lukić, 2006; Uzunović, 2004). This paper explores the repetitive and the explosive muscle potential of the caudal part of the body of sport dancers. Bearing in mind the diversity of techniques of the performance of dance belonging to the discipline of Latin-American and Ballroom dances, there is a need for a different valorization of strength as a motor ability of important for the quality of performance in the mentioned dance disciplines. The level of influence of strength on the LatinAmerican dance performance technique in comparison to Ballroom dances is the topic of this paper. Given the facts stated above, the objective is to determine the form of the correlation between strength and Latin-American and Ballroom dances. The hypotheses of the paper are:

- $\mathrm{H}_{1}$ - statistically important prediction of efficiency of performance techniques of Ballroom dances, based on motoric strength ability, is expected;

- $\mathrm{H}_{2}$ - statistically significant prediction of efficiency of performance techniques of LatinAmerican dances, on the basis of the motoric strength ability, is expected.

\section{METHODS}

\section{Sample of participants}

A representative, purposeful and stratified sample of interviewees was used, comprising 49 sport dancers, of whom 25 female and 24 male dancers. The sample encompassed dancers from 12 to 15 years of age, belonging to the age cohort of juniors 1 and juniors 2. They compete as part of dance divisions D3 and D4, whose program covers choreographies assembled from basic and more complex elements of dance performance techniques. They have all actively participated in the training process for 2 years and have trainings three times a week.

\section{Sample of variables}

For the purposes of this research, one predicative (defined through 3 strength tests) and two criterion variables (defined through 3 Latin-American (LA) and 3 Ballroom (ST) dances have been selected. The predicative variable will serve to test the correlation and possible predication of successfulness in performance of Latin-American and Ballroom dances. It is comprised of: 1 upper body lifting - MPGDT; 2. Throwing medical ball from the lying position -
MBMLE ; 3. Jump from the spot - SKOKUDAL. The predicative variable is made of standardized tests for the evaluation of the motoric strength ability and they possess the necessary metric characteristic (Metikoš, Hofman, Prot, Pintar, \& Oreb, 1989). The criterion variables of Latin-American dances (LA) and Ballroom dances (ST) will be used to assess the speed and the quality of the acquisition of the tasked dance structures. The criterion variable is comprised of three out of the total of five ST dances. Due to mutual contrasting in the dynamics and the paste of performing LA dances, we selected Samba, Cha cha cha and Jive, and from ST dances we selected the English waltz, Tango and Quick step. Each of these dances is defined by the basic technique elements (Howard, 2002; Laird, 1992) and, put together, they comprise a criterion of Latin-American dances and one criterion of Ballroom dances. All technique elements have been prescribed and adopted by the International Dance Sport Federation-IDSF. The assessment of the quality of the basic technique elements of Latin-American and Ballroom dances was done by a jury commission using marks ranging from 0 to 10. The jury commission was comprised of licensed referees of sport dance of the Bosnia and Herzegovina Sport Dance Association.

\section{Test description}

The predication variable system is made of standardized tests for the assessment of the strength motor ability: MPGDT, MBMLE and SKOKUDAL. These tests possess the necessary metric features. Testing the criterion variables was done by a verified jury commission, which simultaneously also assessed thequality of performance (Nagode-Ambrož, 1992) of the tasked dance structures on the scale of 0 to 10 points. The arithmetic mean result of all points will be used to place the obtained values of each interviewee into the basic elements of Latin-American (LA) and Ballroom (ST) dances quality assessment scale.

\section{Quality of performance of different dance structures of LA and ST dances assessment scale:}

\begin{tabular}{cl}
\hline Point & \\
\hline 0 & $\begin{array}{l}\text { None of the elements successfully per- } \\
\text { formed. }\end{array}$ \\
\hline 1 & $\begin{array}{l}\text { One element correctly performed, but } \\
\text { out of the rhythm. }\end{array}$ \\
\hline
\end{tabular}




\begin{tabular}{cl}
\hline 2 & $\begin{array}{l}\text { One element correctly performed in } \\
\text { rhythm, but others poorly and out of the } \\
\text { rhythm. }\end{array}$ \\
\hline 3 & $\begin{array}{l}\text { One element performed in rhythm, but } \\
\text { others performed in a wrong sequence } \\
\text { and out of the rhythm. }\end{array}$ \\
\hline 4 & $\begin{array}{l}\text { Two elements correctly performed, but } \\
\text { out of the music rhythm. }\end{array}$ \\
\hline 5 & $\begin{array}{l}\text { Two elements correctly performed in } \\
\text { rhythm, but others performed out of the } \\
\text { rhythm. }\end{array}$ \\
\hline 6 & $\begin{array}{l}\text { Elements performed in a correct sequen- } \\
\text { ce, but without a rhythm. }\end{array}$ \\
\hline 7 & $\begin{array}{l}\text { Elements performed in a correct sequen- } \\
\text { ce, but only two in the rhythm. }\end{array}$ \\
\hline 8 & $\begin{array}{l}\text { Elements performed in a correct sequen- } \\
\text { ce, but occasionally out of the rhythm. }\end{array}$ \\
\hline 9 & $\begin{array}{l}\text { Elements performed in a sequence and } \\
\text { rhythm, but without the presentation of } \\
\text { the move characteristic. }\end{array}$ \\
\hline 10 & $\begin{array}{l}\text { Elements performed in rhythm, sequen- } \\
\text { ces and with a good presentation of the } \\
\text { move characteristics. }\end{array}$ \\
\hline
\end{tabular}

\section{Statistical data processing}

The results obtained from the research have been processed using the procedures of descriptive and comparative statistical analyses. For comparative statistics, we used the parameteric statistics, and within it: correlational and regressiona analyses. As the level of statistical importance, we set $p<.05$. The statistical data processing was done on a personal computer Pentium IV, with the use of the aplication statistical programs SPSS (version 10.0) and Statistics.

\section{RESULT AND DISCUSSION}

Table 1 shows the correlation matrix of strength and efficiency in performing Ballroom (ST) dance techniques. It is obvious in the table that the efficiency of performance of Ballroom dances is under a big influence of the long jump test, which is representative of explosive strength (.300). Ballroom dances are performed in pair, in a compact hold, in which the upper part of the body of the dancers is at rest. The stability of the dancer depends exactly on the correct positioning of the upper part of the body and its stillness in a progressive move character which dominates in standard dances. Taking that into consideration, it is perfectly understandable that there is absence of statistical significance of correlation link between the other two tests which are representative of repetitive and explosive strength of the upper part of the body. The explosive strength of the legs is a motoric ability which is exhibited in ST dances in lifting and lowering the body axis as a consequence of activating the leg muscles, and in quick dances (such as Quick step) it becomes particularly apparent. The long jump test - SKOKUDAL, trains explosive strength of lower extremities, and in such an explanation lies the logical link between the obtained results. Table 2 shows the results of multiple correlation $(R=.312)$ which provide information of qualitative correlation between the predicative and the criterion variables and the regressive coefficient $\left(R^{2}\right.$ $=.098$ ) which points out to the regressive impact of the predication variable on the criterion. The multiple correlation coefficient $(R)$ shows a very small correlation between the strength motoric ability and the efficiency of performing basic elements of Ballroom dance techniques. The regression coefficient is very low and explains $9.8 \%$ of the mutual variability with the criterion, which points out to the absence of predicative influence on it. Table 3 shows the values of the standardized Beta vector which are positive, but not sufficiently statistically significant for a possible prediction of the criterion variable. Strength as a motoric ability does not have a large influence on the efficiency of performance of basic technique element performance of Ballroom dances for the reason that the technical requirements there boil down to correct use of certain parts of the foot while moving, move control in space and harmonization of such moves with music paste and rhythm (Lukić, 2006). Ballroom dances are performed with circular moves on the dance floor and the dancers always have the task to show the characteristics of the temperament of each dance, and their common facet is a wave-like, soft and elegant presentation of choreographic moves. Dance figures comprising the choreography for each dance ("little routine") criterion variables in beginners (Associate) dance level do not really have big demands in terms of exhibiting strength (particularly repetitive), such as the case in the presentation of the temperament of Latin American (LA) dances (Howard, 2002). Similar findings were confirmed in the research on the influence of strength on the successfulness of Ballroom dance performance (Uzunović, 2004) where the aspects of strength exhibition in sport dance were viewed separately for each dance for female and male dancers. 
TABLE 1

Correlation matrix of strength and standard dances

\begin{tabular}{ll}
\hline Motor abilities & ST \\
\hline MPGDT & .195 \\
\hline MBMLE & .220 \\
\hline SKOKUDAL & $\mathbf{. 3 0 0 ^ { * }}$ \\
\hline * Correlation is significant at the .05 level
\end{tabular}

Legend: ST - Ballroom dances; MPGDT - upper body lifting; MBMLE - throwing medical ball from the lying position; SKOKUDAL - jump from the spot.

TABLE 3

Regression analysis of strength and standard dances
TABLE 2

Regression analysis of strength and standard dances

\begin{tabular}{llrcc}
\hline$R$ & $R^{2}$ & Std. Error & $F$ & $p$ \\
\hline .312 & .098 & 1.437 & 1.623 & .197 \\
\hline
\end{tabular}

a. Predictors: (Constant), MPGDT, MBMLE, SKOKUDAL

Legend: $R$ - multiple correlation coefficient; $R^{2}-$ determination coefficient; Std. Error - standarda error of estimate; $F-F$-ratio; $p$ - statistical significance.

\begin{tabular}{|c|c|c|c|c|c|c|}
\hline \multirow[t]{2}{*}{ Model } & & \multicolumn{2}{|c|}{$\begin{array}{l}\text { Unstandardized } \\
\text { Coefficients }\end{array}$} & \multirow{2}{*}{$\begin{array}{c}\begin{array}{c}\text { Standardized } \\
\text { Coefficients }\end{array} \\
\text { Beta } \\
\end{array}$} & \multirow[t]{2}{*}{$t$} & \multirow{2}{*}{$p$} \\
\hline & & $\mathrm{B}$ & Std. Error & & & \\
\hline \multirow{4}{*}{1} & (Constant) & 2.980 & 2.325 & & 1.281 & .207 \\
\hline & MPGDT & .004 & .014 & .054 & .328 & .745 \\
\hline & MBMLE & .020 & .040 & .086 & .516 & .608 \\
\hline & SKOKUDAL & .019 & .016 & .227 & 1.224 & .227 \\
\hline
\end{tabular}

a. Predictors: (Constant), MPGDT, MBMLE, SKOKUDAL

b. Dependent Variable: ST

Legend: MPGDT - upper body lifting; MBMLE - throwing medical ball from the lying position; SKOKUDAL - jump from the spot; $\mathbf{B}$ - beta coefficient; $t-t$-value; $p$ - statistical significance; $\mathbf{S T}$ - standard dances.

Of all the tests defining the strength influence, only the explosive strength test for both genders turned to be statistically important, but its contribution did not have the ultimate statistical importance in the strength domain. At higher dance levels however, Member and Fellow, where complex dance choreographiesare performed with the interpretation of numerous syncope steps and plays with the tempo and tact of the music, it should be known that strength as a motoric ability surely becomes apparent and becomes an indispensible facet of the entire dance expression. This research showed the absence of the regressive influence, which is only logical given the said manifestation characteristics of selected dance choreographies while requirements at this dance level were not high.

Table 4 shows the correlation analysis of strength and efficiency of performance of Latin-American dances. It is obvious from the table that the two strength tests show a statistically significant correlation with the Latin-American dance performance technique. Strength as a motoric ability in Latin-American dances becomes apparent with the increase of bodily expression while presenting the character of the dance that is being performed. In some dances (Samba and Cha-cha-cha), it is exhibited through the abdominal part of the body (MPGDT - .434) when presenting an expressive swaying the hips and moving the stomach muscles, and in some (Jive), in the form of explosive strength of the legs (SKOKUDAL - .432) when performing a correct basic sways (basic movement) typical for Jive. The results are presented in the table 5 and they point out to a high multiple correlational links between the predicative and criterion variables $(R)$ at the level of .511. The determination coefficient $\left(R^{2}\right)$ which determines the predicative importance of the strength ability for the efficiency of performance of the basic elements of the LA dance technique is 261 . That means that $26 \%$ of the explained variability of the criterion variable is set by the predicative variable. The remaining $84 \%$ is under the influence of unexplained factors. On the basis of the $F$ test, it is concluded that on the basis of the motoric strength ability, the successfulness of the 
performance of the basic elements of the LA dance technique can be predicted. These parametric values are important at the .003 level. Table 6 shows Beta coefficients providing information on the partial influence of each test on the efficiency of performance of basic elements of the LA dance technique. A statistically significant influence (.041) is seen in the long jump from the spot test - SKOKUDAL, which is one of the forms of showing explosive strength of the legs. Latin-American dances - Samba and Jive in the technical performance of the basic steps are characterized by the so called "bounce" action of the body consisting of flexing and extending the jump joint and the knee joint (Laird, 1992). This activity is done at the speed directed by the music tempo, and if we take into consideration that these two dances are among the fastest of all Latin-American, the explosive strength ability of the caudal part of the body is of great importance for the efficient, that is, technically correct performance of the dance. The explosive strength test SKOKUDAL -long jump also appears to be important (.053) in the predication of the efficiency of performance of basic LA dances, which is also logical, taking into consideration the tempo (speed) of performance of swift sudden changes of direction and leg changes, which were set as a task throughout all choreographies of the selected LA dances. From all the above, it is obvious that explosive strength is one of the most common forms of strength presentation, at least when it comes to sport dance and this level of dance knowledge. Given its contribu- tion to the total bodily presentation in sport dance, the future research from this motoric aspect could be directed towards examining the importance of strength and its manifestation forms in the highest dance levels and in the levels where premium dance results are achieved.

\section{TABLE 4}

Correlation matrix of strength and Latin-American dances

\begin{tabular}{ll}
\hline Motoric abilities & LA \\
\hline MPGDT & $.434^{*}$ \\
\hline MBMLE & .133 \\
\hline SKOKUDAL & $.432^{*}$ \\
\hline Correlation is significant at the .01 level
\end{tabular}

Legend: LA - Latin-American dances; MPGDT upper body lifting; MBMLE - throwing medical ball from the lying position; SKOKUDAL - jump from the spot.

\section{TABLE 5}

Regression analysis of strength and Latin-American dances

\begin{tabular}{llrll}
\hline$R$ & $R^{2}$ & Std. Error & $F$ & $p$ \\
\hline .511 & .261 & 1.030 & 5.292 & .003 \\
\hline
\end{tabular}

a. Predictors: (Constant), MPGDT, MBMLE, SKOKUDAL

Legend: $R$ - multiple correlation coefficient; $R^{2}-$ determination coefficient; Std. Error - standarda error of estimate; $F-F$-ratio; $p$ - statistical significance.

\section{TABLE 6}

Regression analysis of strength and Latin-American dances

\begin{tabular}{|c|c|c|c|c|c|c|}
\hline \multirow[t]{2}{*}{ Model } & & \multicolumn{2}{|c|}{$\begin{array}{c}\text { Unstandardized } \\
\text { Coefficients } \\
\end{array}$} & \multirow{2}{*}{$\begin{array}{c}\text { Standardized } \\
\text { Coefficients } \\
\text { Beta } \\
\end{array}$} & \multirow[t]{2}{*}{$t$} & \multirow[t]{2}{*}{$p$} \\
\hline & & $\mathrm{B}$ & Std. Error & & & \\
\hline \multirow{4}{*}{1} & (Constant) & 2.864 & 1.668 & & 1.718 & .093 \\
\hline & MPGDT & .019 & .010 & .290 & 1.940 & .059 \\
\hline & MBMLE & -.025 & .028 & -.131 & -.893 & .377 \\
\hline & SKOKUDAI & .024 & .011 & .354 & 2.104 & .041 \\
\hline
\end{tabular}

a. Predictors: (Constant), MPGDT, MBMLE, SKOKUDAL

b. Dependent Variable: LA

Legend: MPGDT - upper body lifting; MBMLE - throwing medical ball from the lying position; SKOKUDAL - jump from the spot; $\mathbf{B}$ - beta coefficient; $t$ - $t$-value; $p$ - statistical significance; LA - Latin-American dances. 


\section{CONCLUSION}

The examination of the relevance of the influence of strength on the sport dance performance technique was implemented on a representative sample of sport dance dancers, age 12 to 15 . The predicative variable was comprised of three tests of strength: MPGDT, MBMLE and SKOKUDAL, and the criterion variable elements of the technique of selected Latin-American and Ballroom dances. On the basis of the analysis of the results obtained and their interpretation, the following conclusions have been drawn:

- From the regressionanalysis results it can be concluded that the motoric strength ability cannot serve to predict the efficiency of performance of the Ballroom dance technique elements. There is a correlation with explosive strength, but it is not high enough to establish a positive regression between strength and Ballroom dances.

- From the regression analysis results, it can be concluded that strength can serve to predict the efficiency of performance of the Latin-American dance technique elements.

The results show that the strength aspect does provide a large contribution to the successfulness of performance of Latin-American dances, unlike the situation in the Ballroom dances. In this dance discipline too, there is a statistically significant importance of explosive muscle potential, which points out to the fact that conditional training of dancers, at least when it comes to strength, needs to be focused on this type of its action manifestation. The obtained results show the necessity of having a separate approach to planning and programming the training process particularly for Latin-American dances, given the diversity in dynamics, technique, time and special requirements of performance, dance expression, and engaging different motoric potentials. This kind of research is a contribution to a better organization of training process especially when it comes to individual access to training motor skills that have a dominant influence on the technique of particularly Latin American and Ballroom dances. Bearing in mind that there are just a few research in the field of sport dance, and that there is a special need for those who treat the individual effect of motor abilities on the efficiency of the dance performance, it can be said that the contribution of this paper is that it encourages other research projects in which should be looked and studied all aspects that determine the sports result in dance. Open questions, doubts and new ideas that arise when reading this article are some guidelines for new research in the field of sport dance.

\section{REFERENCE}

Howard, G. (2002). The Technique of Ballroom Dancing. Internacional Dance Teachers Association Ltd. Brighton: Publish by International Dance Publications.

Jocić, D. (1991). Predvidanje uspjeha u plesovima na osnovu morfološkog, motornog, kognitivnog $i$ konativnog statusa (Prediction of success in dances based on morphological, motor, cognitive and conative status). Unpublished doctoral dissertation. Univerzitet Beograd, Fakultet fizičke kulture.

Kostić, R. (1997). The Influence of a Two-week training on the Motor Abilities of Female Dancers (Uticaj dvonedeljnog treninga na motoričke sposobnosti plesačica). In R. Kostić (Ed.), Šesti medunarodni simpozijum »FIS komunikacije 1997"u firickeom vaspitanju, sportu i rekreaciji (pp. 107-114). Niš: Filozofski fakultet, Institut fizičke kulture.

Laird, W. (1992). Tecbnique of Latin dancing. Brighton: Publish by International dance Publication.

Lukić, A. (2006). Relacije nekih motoričkih sposobnosti i efikasnosti i zvodenja osnovnih elemenata tehnike u sportskom plesu (Relations between some motor skills and efficiency of performing the basic elements of technique in sport dance). Unpublised Master's thesis. Univerzitet Banja Luka, Fakultet fizičkog vaspitanja i sporta.

Lukić, A., Bijelić, S., \& Jovanović, S. (2008). Uticaj ravnotežze na predikciju uspješnosti u Standardnim plesovima (The influence of balance on prediction of success in the Standard dances). In B. Krsmanović and T. Kaleši (Eds), XVI medunarodni interdisciplinarni simpozijum "Ekologija, sport, firička aktivnost $i$ zdravlje mladih. Novi Sad: Novosadski maraton.

Lukić, A. (2010). Efekti proprioceptivnog treninga na razuijanje ravnotežze i poboljsanje tebnike iəvodenja u sportskom plesu (The effects of proprioceptive training to development of balance and improvement of techniques involved in sport dance). Unpublished doctoral dissertation. Univerzitet Banja Luka, Fakultet fizičkog vaspitanja i sporta. Metikoš, D., Hofman, E., Prot, F., Pintar, Ž., \& Oreb, G. (1989). Mjerenje bazičnih motorickeib dimen₹ija sportaša (Measurement of basic motor dimensions of athletes). Fakultet za fizičku kulturu. Zagreb.

Nagode-Ambrož, B. (1992). Kriterïi sojenja za standardne in latinsko - ameriške plese (The judging criteria for Ballroom and Latin-American dances). Ljubljana: Udruženje plesnih vaditeljev, učiteljev in trenerjev Slovenije. 
Uzunović, S. (2004). Uticaj antropomotorickeih sposobnosti na uspješnost u sportskom plesu (Influence of motor abilities to success in sport dance). Unpublised Master's thesis. Univerzitet Niš, Fakultet fizičke kulture.

Uzunović, S., Kostić, R., Zagorc, M., Oreb, G., \& Jocič, D. (2005). The effect of coordination skills on the success in standard sports dancing (Efekti koordinacije na uspjeh u standardnim plesovima). In N. Dikic, S. Zivanic, S. Ostojic, and Z. Tornjanski (Eds.), Book of Abstracts of 10th Annual Congress European College of Sport Science (pp. 270-271). Belgrade: European College of Sport Science.
Uzunović, S. (2008). The transformation of strength, speed and coordination under the influence of sport dancing (Transformacija snage, brzine i koordinacije pod uticajem modernog sportskog plesa). Facta Universitas, 6, 135-146.

Vlašić J., Oreb, G., \& Leščić, S. (2009). Povezanost motoričkih i morfoloških obilježja s uspjebom u drustvenim plesovima (Relationship between motor and morphological characteristics with the success in social dances). Hrvatski sportskomedicinski vijesnik, 30-37.Vlašić J., Oreb, G. i Lešćić, S. (2009). Povezanost motoričkih i morfoloških obilježja s uspjehom u drustvenim plesovima. Hrvatski sportskomedicinski vijesnik, 30-37.

Received: September 29, 2010 Accepted: April 15, 2011

Correspodence to: Adriana Lukić, $\mathrm{PhD}$ Faculty of Physical Education and Sport

Bul. Petra Bojovića 1A 78000 Banja Luka Bosnia and Herzegovina Phone: 0038765567612 E-mail: adri.lukic@gmail.com 